\title{
THE EFFECT OF CERTAIN BIOCONTROL AGENT ON SOME BIOLOGICAL, BIOCHEMICAL AND HISTOLOGICAL ASPECTS OF THE COTTON LEAF WORM SPODOPTERA LITTORALIS (BOISD.) (LEPIDOPTERA: NOCTUIDAE)
}

\author{
ABD-EL WAHED, M. S. ${ }^{1}$, FAYZA M. AHMED ${ }^{1}$,AZIZA E. ABDEL-AAL ${ }^{2}$ \\ AND MARWA M. ABDEL-AZIZ. ${ }^{2}$ \\ 1. Department of Plant Protection, Faculty of Agriculture, Ain Shams University, \\ Shobra El-Kheima, Cairo \\ 2. Plant Protection research Institute, ARC, Giza
}

(Manuscript received 28 July 2010)

\begin{abstract}
The potency of three commercial bio-insecticides, Protecto namely, Bacillus thuringiensis var. kurstaki, Viruset, Spodoptera littoralis Nuclear Polyhydrosis Virus, SLNPV and their mixture Profect were evaluated against the cotton leaf-worm, Spodoptera littoralis(Boisd.) (Lepidoptera: Noctuidae). Protecto proved to be more toxic on both $2^{\text {nd }}$ instar larvae than the two other tested bioagents, Viruset was more effective on $4^{\text {th }}$ instar larvae than Profect. $\mathrm{LC}_{90}$ and $\mathrm{LC}_{50}$ for Viruset were $1 \times 10^{6}$ and $1 \times 10^{3} \mathrm{PIBs} / \mathrm{ml}$, respectively, corresponding values were $5 \times 10^{8}+1.6 \times 10^{7}$ and $5 \times 10^{4}$ $+1.6 \times 10^{3} \mathrm{PIBs} / \mathrm{ml}+\mathrm{IU} / \mathrm{ml}$ when Profect was tested. The tested bioagents reduced larval duration, percentages of larval pupation as well as adult emergence of $S$. littoralis fed as $2^{\text {nd }}$ instar larvae on castor oil leaves treated with $\mathrm{LC}_{50}$. The digestive enzymes amylase and invertase and trehalase were determined in $6^{\text {th }}$ instar larvae surviving treatment of $2^{\text {nd }}$ instar larvae with $\mathrm{LC}_{50}$ of the tested three bioagents. Amylase activity in treated larvae was found to be significantly higher in all treatments. Similarly, except in case of Viruset, invertase activity was increased. Meanwhile, the three tested compounds caused a significant decrease in trehalase activity.Midgut histological sections were carried out on $6^{\text {th }}$ instar larvae treated as $4^{\text {th }}$ instar larvae with $\mathrm{LC}_{50}$ of the three tested compounds. Profect was the most effective product in causing aberrations in the midgut layers, following by Protecto and Viruset.

Key words: Cotton leaf- worm, Spodoptera littoralis, Bacillus thuringiensis var. kurstaki, Nuclear Polyhydrosis Virus, digestive enzymes, midgut histopathology., insectcidal actievities.
\end{abstract}

\section{INTRODUCTION}

The entomopathogenic bacteria, Bacillus thuringiensis represents a good example for biological controlof insect pests. This bacterium, proved to be a highly successful for controlling some agricultural insect pests (Mohamed et al., 2005).

The present study was undertaken to evaluate the use of three bioagents, the bacteria (Bacillus thuringiensis var. kurstakl) "Protecto", the (Spodoptera littoralis Nuclear Polyhydrosis Virus, SLNPV) "Viruset" and a commercial mixture of both 
432 THE EFFECT OF CERTAIN BIOCONTROL AGENT ON SOME BIOLOGICAL, BIOCHEMICAL AND HISTOLOGICAL ASPECTS OF THE COTTON LEAF WORM SPODOPTERA LITTORALIS (BOISD.)

(LEPIDOPTERA: NOCTUIDAE)

"Profect", for the control of $S$. littoralis (Boisd). The study was mainly concerned with the evaluation of these compounds toxicity and their bioassay on $S$. littoralis larvae as well as their effects on larval growth and development.

A histopathological study was also conducted in the midgut of $6^{\text {th }}$ instar larvae surviving treatment. Furthermore, the activity of three carbohydrates enzymes was evaluated in larvae treated as $4^{\text {th }}$ instars.

\section{MATERIALS AND METHODS}

\section{Rearing technique:}

A stock culture of the cotton leaf worm, S. littoralis was obtained from a laboratory strain maintained at the Cotton Pest Research Department.Plant Protection Research Institute, Agriculture Research Center, Dokki, Giza, for several generations without any insecticidal pressure. The insect was reared on castor-oil leaves, Ricinus communis, under laboratory conditions at $25 \pm 2^{\circ} \mathrm{C}$ and $60 \pm 5 \%$ R.H.

\section{Tested compounds:-}

The potency of the three tested bioagents were evaluated for their effect on $S$. littoralis larvae:- Bacillus thuringiensis var. kurstaki (Protecto) Spodoptera littoralis Nuclear Polyhydrosis Virus (SLNPV),(Viruset)and their binary mixture (Profect). The three mentioned microbial agents were obtained from Plant Protection Research Institute Biopesticide Unit Production.

\section{Bioassay:-}

The insecticidal activities of the three tested bioagents were assessed on newly ecdysed $2^{\text {nd }}$ instar $S$. littoralis larvae.

A series of dilutions were prepared from $1 \mathrm{gm}$ of the product obtained as wettable powder, $6.4 \times 10^{6}, 3.2 \times 10^{5}, 3.2 \times 10^{4}, 3.2 \times 10^{3}, 3.2 \times 10^{2}$ and $3.2 \times 10 \mathrm{IU} / \mathrm{ml}$ of Protecto. (IU= International Unit)., $1 \times 10^{7}, 1 \times 10^{6}, 1 \times 10^{5}, 1 \times 10^{4}, 1 \times 10^{3}, 1 \times 10^{2}$ and $1 \times 10 \mathrm{PIBs} / \mathrm{ml}$. (PIBs $=$ Polyhedral Inclusion Bodies)of Viruset and $5 \times 10^{8}+1.6 \times 10^{7}, 5 \times 10^{6}+1.6 \times 10^{5}$, $5 \times 10^{5}+1.6 \times 10^{4}, 5 \times 10^{4}+1.6 \times 10^{3}, 5 \times 10^{3}+1.6 \times 10^{2}, 5 \times 10^{2}+1.6 \times 10$ and $5 \times 10+1.6$ $\mathrm{PIBs} / \mathrm{ml}+\mathrm{IU} / \mathrm{ml}$ of Profect.

Treatment of larvae was conducted by the leaf dipping technique, Mortality was recorded daily and accumulative larval mortality was determined at the end of the larval stage. The mortality percentages were corrected by Abbott's formula (Abbott, 1925). Results were illustrated graphically as log/probit regression lines, and toxicity $\mathrm{LC}_{90}$ and $\mathrm{LC}_{50}$ values as well as the slope were obtaind according to Finney, (1971). 


\section{Biological studies:}

Anewly ecdysed $2^{\text {nd }}$ instars larvae were offered castor oil leaves treated with the determined $\mathrm{LC}_{50}$ of each of the tested compounds for $24 \mathrm{hr}$., and then reared on untreated leaves. The number of treated larvae was 20 larvae placed in sets of five and each experiment was replicated 3 times. The following biological aspects were determined Larval duration, percentage pupation, pupal weight, pupal stage duration, adult emergence and life span of adult moths.

\section{Biochemical studies:-}

The activity of three carbohydrate enzymes :- invertase, amylase and trehalase was determined in $6^{\text {th }}$ instars larvae surviving treatment of $2^{\text {nd }}$ instars with $L C_{50}$ of each the three tested compounds, as described by Ishaaya and Swirski, (1970) and Ishaaya et al., (1971).

\section{Histopathological studies}

The effect of each of the three tested compounds at $\mathrm{LC}_{50}$ values was studied on the cellular structure of the mid gut of $6^{\text {th }}$ instar larvae surviving treatment of $2^{\text {nd }}$ instars larvae with the $L_{50}$ values. Larvae were dissected in Ringer solution and their mid guts rapidly removed and placed in aqueous Bouin's solution for $24 \mathrm{hrs}$. for fixation. Specimens were washed in water, dehydrated in a series of ethyl alcohols and cleared in xylene; paraffin wax embedding procedure was then followed. Cross sections were cut at $6 \mu$ thickness, using a microtome, and mounted on glass slides. Sections were stained with Heamatoxylin and counterstained in alcoholic aqueous Eosin for microscopic examination. Similarly, sections of the mid gut of non-treated larvae were also prepared for comparison.

\subsection{Statistical analysis:-}

Statistical analysis (ANOVA) of the obtained data was performed by using COSTAT program, which run under WIN. Also the difference between means was conducted by using Duncan's multiple range tests in this program.

\section{RESULTS}

\section{Insecticidal activities:-}

The efficiency of the, three bioagents were evaluated on $2^{\text {nd }}$ instars larvae of $S$ littoralis (Boisd.).The results indicated that Protecto (Bacillus thuringiensis var. kurstakl) gave the highest larvicidal activity as compared to the other two bioagents. The $\mathrm{LC}_{90}$ and $\mathrm{LC}_{50}$ for $2^{\text {nd }}$ instar larvae were $6.4 \times 10^{6}$ and $3.2 \times 10^{2} \mathrm{IU} / \mathrm{ml}$. respectively (Table1). The slope values were 0.37 and 0.31 for $2^{\text {nd }}$ instars larvae, respectively, which proved the homogeneity of the tested larvae. 
The bioagent Viruset (Spodoptera littoralis Nuclear Polyhydrosis Virus, SLNPV) exhibited an intermediate toxic effect to treated larvae, while the bioagent Profect which is a mixture of $B t$ and the SLNPV proved to be the least toxic to both treated larval instars as depicted by the calculated $L C$ values. Also the determined $\mathrm{LT}_{50,} \mathrm{~s}$ of the tested bioagents recorded $12.02,12.47$ and 14.12 days to the treatments by Protecto, Viruset and Profect, respectively (Table 1) .

Table 1. Susceptibility of Spodoptera littoralis $2^{\text {nd }}$ instar larvae to three bioinsecticides.

\begin{tabular}{|c|c|c|c|c|c|c|}
\hline Compound & Unit & $\mathrm{LC}_{90}$ & $\mathrm{LC}_{50}$ & Slope & $\mathrm{LT}_{50}$ & Slope \\
\hline Protecto & $\mathrm{IU} / \mathrm{ml}$ & $6.4 \times 10^{6}$ & $3.2 \times 10^{2}$ & 0.37 & 12.02 & 2.49 \\
\hline Viruset & $\mathrm{PIBs} / \mathrm{ml}$ & $1 \times 10^{7}$ & $1 \times 10^{2}$ & 0.19 & 12.47 & 5.24 \\
\hline Profect & $\begin{array}{l}\mathrm{PIBs} / \mathrm{ml} \\
+\mathrm{IU} / \mathrm{ml}\end{array}$ & $\begin{array}{l}5 \times 10^{8}+ \\
1.6 \times 10^{7}\end{array}$ & $\begin{array}{l}5 \times 10^{3}+ \\
1.6 \times 10^{2}\end{array}$ & 0.33 & 14.12 & 9.53 \\
\hline
\end{tabular}

\section{Biological effects of the three tested bioagents on $S$. littoralis (Boisd.) treated as $2^{\text {nd }}$ instars larvae:}

\subsection{Effects on the development of S. littoralis:-}

The result in Table 2 indicated that there was no effect on the larval duration as the result of treatment the $S$. littoralis $2^{\text {nd }}$ instars by $L_{50}$ of the three tested bioagents recorded $14.5 \pm 0.4,15 \pm 0.4,15 \pm 0.3$ days for Protecto ,Viruset and profect respectively compared to $15 \pm 0.4$ days in control. However, treatment with Protecto insignificantly slightly shortened the larval duration than the control by 0.5 day (Table 2).

The percentage of larvae treated as $2^{\text {nd }}$ instars with $L C_{50}$ of the three bioagents metamorphosing to pupae was markedly reduced to approximately half the value of their control (Table 2). Pupation percentage of $47.5,50$ and $52.2 \%$, recorded when Protecto, Viruset and Profect were tested respectively.

It is noteworthy, that the weight of the apparently normal appearing pupae soon after pupation developing from treated larvae was comparable to the control and no differences were found recorded a mean of $0.35 \mathrm{mg}$.

Under conditions of the present work, in untreated insects the pupal stage lasted 13.6 days, this period was shortened to 11.3 days ; i.e. less by 2.3 days , when $\mathrm{LC}_{50}$ of Protecto or Viruset was used and to 12.6 days with the application of Profect i.e. less by 1 day. These differences were found to be statistically significant (Table 2).

Percentage of adult ecolosion was affected as result of treatment of $2^{\text {nd }}$ instar larvae with $\mathrm{LC}_{50}$ of the three bioagents, it was less than the control by $37.4 \%, 40 \%$ and $42 \%$ 
when $\mathrm{LC}_{50}$ of Protecto, Viruset and Profect were tested, respectively (Table 2). Life span of moths was an average of $12.67,13.67$ and 16 days to the respective mentioned bioagents, as compared to 12.33 days in untreated insects.

Table 2. Percentages of pupation, mean pupal duration and adult emergence $\%$ of $S$. littoralis fed as $2^{\text {nd }}$ instar larvae on castor oil leaves treated with $\mathrm{LC}_{50}$ of Protecto, Viruset and Profect.

\begin{tabular}{|c|c|c|c|c|}
\hline Compound & $\begin{array}{c}\text { Mean larval } \\
\text { duration } \\
\text { (days } \pm \text { S.E.) }\end{array}$ & $\begin{array}{c}\text { Pupation } \\
\%\end{array}$ & $\begin{array}{c}\text { Pupal stage } \\
\text { duration } \\
\text { (days } \pm \text { S.E.) }\end{array}$ & \% Adult emergence \\
\hline Protecto & $14.5 \pm 0.4^{\mathrm{a}}$ & $47.5^{\mathrm{c}}$ & $11.3 \pm 0.3^{\mathrm{c}}$ & $79^{\mathrm{b}}$ \\
\hline Viruset & $15 \pm 0.4^{\mathrm{a}}$ & $50^{\mathrm{bc}}$ & $11.3 \pm 0.6^{\mathrm{c}}$ & $80^{\mathrm{b}}$ \\
\hline Profect & $15 \pm 0.3^{\mathrm{a}}$ & $52.2^{\mathrm{b}}$ & $12.6 \pm 0.1^{\mathrm{b}}$ & $80.9^{\mathrm{b}}$ \\
\hline Control & $15 \pm 0.2^{\mathrm{a}}$ & $100^{\mathrm{a}}$ & $13.6 \pm 0.3^{\mathrm{a}}$ & $100^{\mathrm{a}}$ \\
\hline F values & $4.836^{*}$ & $293.594^{* * *}$ & $21.34^{* * *}$ & $60.3636^{* * *}$ \\
\hline L.S.D. & $1.25^{*}$ & 4.20605 & 0.67 & 4.3028 \\
\hline
\end{tabular}

Means with the same letter are not significantly different $(p<0.05)$.

\section{Biochemical studies:}

The effects of $\mathrm{LC}_{50}$ of Protecto, Viruset and Profect on the activities of three carbohydrate digestive enzymes in $S$. littoralis $6^{\text {th }}$ instar larvae treated as $2^{\text {nd }}$ instars larvae was estimated (Table 3). In untreated larvae amylase activities were found to be $205.4 \mathrm{\mu g}$ glucose/min $/ \mathrm{gm}$. Following treatment with $\mathrm{LC}_{50}$ of Protecto, Viruset or Profect, the activity of amylase was significantly increased to $330.5,209.8$ and $285 \mu \mathrm{g}$ glucose/min /gm., respectively.

Invertase activity was $478.2 \mu \mathrm{g}$ glucose/min $/ \mathrm{gm}$. in untreated larvae this level was relatively unaffected in treated larvae with $\mathrm{LC}_{50}$ of Viruset i.e. $474.2 \mu \mathrm{g}$ glucose/min /gm. Meanwhile, when Protecto or Profect were used at $\mathrm{LC}_{50}$ values, invertase activity was significantly decreased to 405 , and $432 \mu \mathrm{g}$ glucose/min /gm., respectively. Meanwhile, trehalase activity was highly significantly decreased from 313.5 in untreated larvae to 303.2, 196.9 and $262 \mu \mathrm{g}$ glucose/min /gm. in larvae treated with Protecto, Viruset and Profect, respectively. 
Table 3. Activity of amylase, invertase and trehalase in $6^{\text {th }}$ instar larvae of $S$. littoralis treated with $\mathrm{LC}_{50}$ of Protecto, Viruset and Profect as $2^{\text {nd }}$ instar larvae.

\begin{tabular}{|c|c|c|c|}
\hline \multirow{2}{*}{ Treatments } & \multicolumn{3}{|c|}{ Mean carbohydrases activity $\mu$ g glucose/min /gm. \pm S. E. } \\
\cline { 2 - 4 } & Amylase & Invertase & Trehalase \\
\hline Protecto & $330.5 \pm 0.2^{\mathrm{a}}$ & $405.0 \pm 1.2^{\mathrm{c}}$ & $303.2^{\mathrm{a}} \pm 0.1^{\mathrm{b}}$ \\
\hline Viruset & $209.8 \pm 0.2^{\mathrm{d}}$ & $474.2 \pm 0.1^{\mathrm{a}}$ & $196.9 \pm 0.5^{\mathrm{e}}$ \\
\hline Profect & $285 \pm 0.6^{\mathrm{c}}$ & $432 \pm 0.3^{\mathrm{b}}$ & $262^{\mathrm{b}} \pm 0.2^{\mathrm{c}}$ \\
\hline Control & $205.4 \pm 0.2^{\mathrm{e}}$ & $478.2 \pm 0.1^{\mathrm{a}}$ & $313.5^{\mathrm{a}} \pm 0.3^{\mathrm{a}}$ \\
\hline F values & $1760.026^{* * *}$ & $4558.533^{* * *}$ & $7798.393^{* * *}$ \\
\hline L.S.D & 4.175 & 4.41 & $1.883^{\circ}$ \\
\hline
\end{tabular}

Means with the same letter are not significantly different $(p<0.05)$.

\section{Histopathological studies:-}

The histological structure of midgut in larvae of Lepidoptera is well documented (Chapman, 1988). As seen in Fig.1 the mid gut is lined with an epithelial layer, which rests on a basement membrane, and is composed of a single layer of three types of cells. (i) A majority of columnar cells containing a large coarse nucleus which occupies a middle position within the cell and bears a striated or brush-like border (microvilli). (ii) Goblet cells; which are somewhat calyx-shaped and are seen between the columnar cells; each of these cells has a large ampulla opening by a narrow neck through a small aperture on the inner surface. (iii) Regenerative cells are small in size and rest on the basement membrane between the bases of the other cells, and are round or elongated and contains a large nucleus surrounded by a small amount of strongly basophilic cytoplasm.

Within the midgut lumen, there is a thin peritrophic membrane, that surrounds the food mass. A musculosa surrounds the epithelial layer, composed of an inner circular layer and an outer layer of longitudinal muscle.

The histological structure of $6^{\text {th }}$ instar larvae surviving their treatment with $\mathrm{LC}_{50}$ of the three bioagents as $2^{\text {nd }}$ instar larvae appears somewhere impaired. Induced cellular changes were relatively similar when either of the bioagents were tested. However, they were more enhanced where Profect was tested. Generally, the changes in the histological structure of midgut could be summarized as follows:-

i. The lumen of the gut appears somewhere collapsed and globular bodies and cytoplasmic fragments were observed pinching off from the tip of some of the epithelial cells vicinal to the deteriorated peritrophic membrane. This observation was most apparent when Protecto was tested. (Fig.2). 
ii. The muscularis layers lose their compact appearance, and the loss of many circular muscles was evident. The peritrophic membrane appears somewhat deteriorated, and the striated border together with the regenerative cells was obliterated when larvae were treatment with Viruset (Fig.3).

iii. Vacuolization in the midgut epithelium and disruption of both the peritrophic membrane and the striated boarder were evident. Some of the degenerated columnar cells were fused with the disrupted peritrophic membrane. This observation was more evident when larvae were treatment with $\mathrm{LC}_{50}$ of Profect (Fig.4).

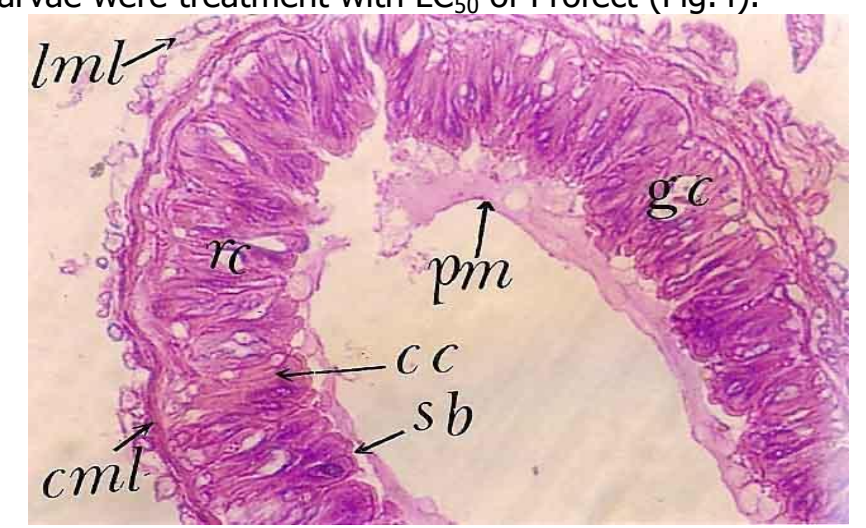

Fig. 1.T. S. in the mid gut of untreated 5 days old $6^{\text {th }}$ instar $S$. littoralis larvae (X 160).

\begin{tabular}{|c|c|}
\hline CC: & columnar cell. \\
\hline $\mathrm{cm} /:$ & circular muscle layer. \\
\hline$g c:$ & goblet cell. \\
\hline Iml: & longitudinal muscle layer. \\
\hline pm : & peritrophic membrane. \\
\hline rc: & regenerative cell. \\
\hline Sb: & striated border. \\
\hline
\end{tabular}


438 THE EFFECT OF CERTAIN BIOCONTROL AGENT ON SOME BIOLOGICAL ,BIOCHEMICAL AND HISTOLOGICAL ASPECTS OF THE COTTON LEAF WORM SPODOPTERA LITTORALIS (BOISD.) (LEPIDOPTERA: NOCTUIDAE)

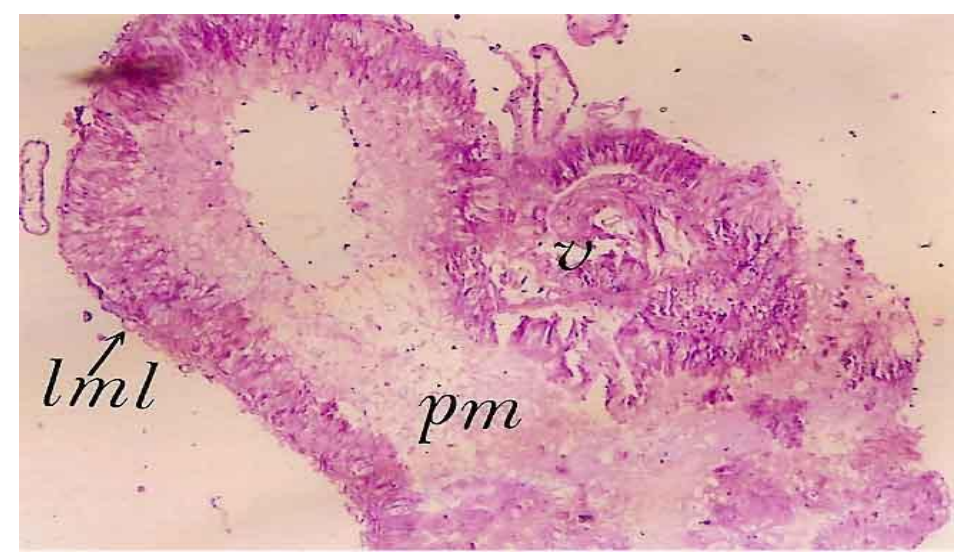

Fig . 2. T. S. in the mid gut of 5 days old $6^{\text {th }}$ instar $S$. littoralis larvae treated with $\mathrm{LC}_{50}$ of Protecto as $4^{\text {th }}$ instars (X 400).

Iml: longitudinal muscle layer.

pm : $\quad$ peritrophic membrane.

V: vacuole.

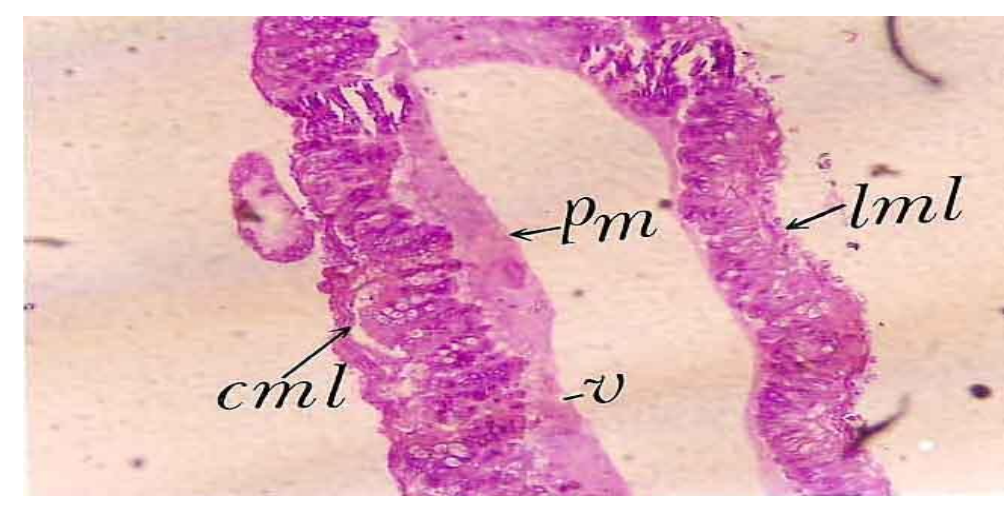

Fig . 3. T. S. in the mid gut of 5 days old $6^{\text {th }}$ instar $S$. littoralis larvae treated with $\mathrm{LC}_{50}$ Viruset as $4^{\text {th }}$ instars (X 400).
cml: $\quad$ circular muscle layer.
Iml: longitudinal muscle layer.
pm : $\quad$ peritrophic membrane.
V: $\quad$ vacuole. 


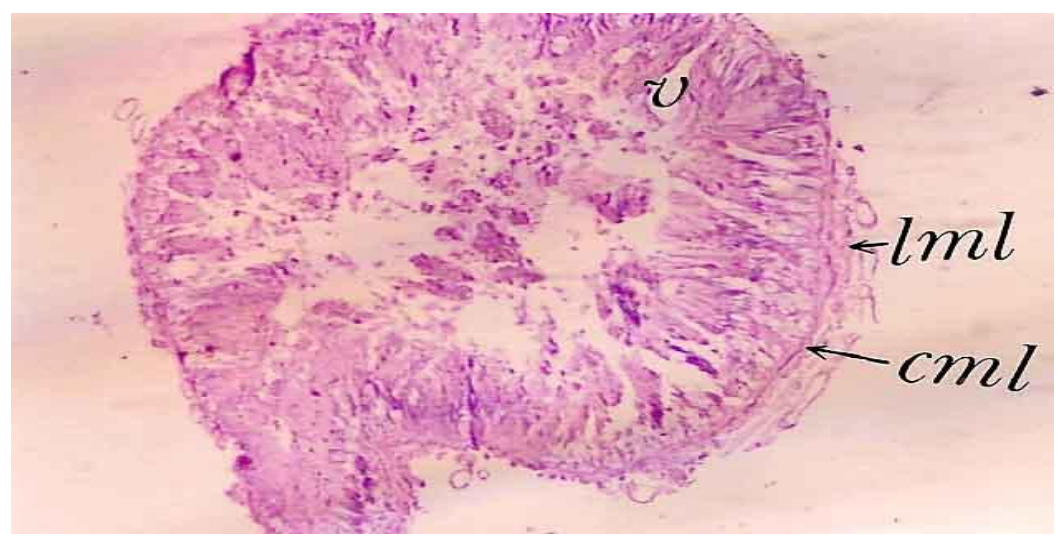

Fig . 4. T. S. in the mid gut of 5 days old $6^{\text {th }}$ instar $S$. littoralis larvae treated with $\mathrm{LC}_{50}$ of Profect as $4^{\text {th }}$ instars (X 400).

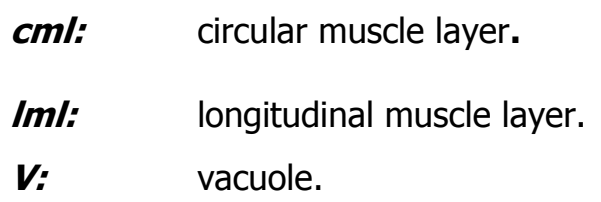

\section{DISCUSSION}

In the present investigation, the potency of three entomopathological bioagents, the bacteria (Bacillus thuringiensis var. kurstakı) "Protecto", the (Spodoptera littoralis Nuclear Polyhydrosis Virus, SLNPV) "Viruset" as well as their mixture "Profect" was assessed.

These bioagents are widely used for the control of many lepidopteran insects (Lacey et al., 2001).In the present work, Protecto exhibited a lower LC values than the other two bioagents, following by Viruset then Profect. Gamil (2004) recorded high rate of mortality in $3^{\text {rd }}$ instar $S$. littoralis larvae treated with Protecto than in SLNPV treated larvae. The median lethal concentration $\mathrm{LC}_{50}$ of the three tested bioagents did not kill larvae rapidly. Therefore mortality rate was low during the first and second days following treatment but their toxic effects became most apparent at the termination of the larval stage. $\mathrm{LT}_{50}$ was similar when either Protecto or Viruset was used, it was slightly extended when Profect was tested.

Treated $2^{\text {nd }}$ instars larvae of $S$. littoralis were susceptible to the bacteria, virus and their mixture, however, younger instar was more susceptible. It is well documented that older instar were usually more tolerant to the toxic effect of many compounds, (Hanafy et al., 2005), these authors showed the considerable variations in susceptibility between bioagents against different instar larvae. 
Treatment with the tested bioagents prolonged the duration of the subsequent larval instar of treated larvae, as well as the pupal stage, also, pupation and adult moth emergence rates were reduced. Mohamed, (2006) reported the delay of ecdysis in larvae treated with NPV. Gamil, (2004) and Mohamed, (2006), also found that the development time of larvae and pupae were extended as well as adult emergence as a result of treatment with bacterial or viral agents. Hegazy and Antonious, (1987) reported the antifeedant effect of thuricide and SAN 415 both containing $B$. thuringiensis on $S$. littoralis this effect was than reflected in reductions of larvae and pupae weights. In the results of the present work, the weight of formed pupae (from treated larvae) was not impaired.

In the present work, a general disturbance in three carbohydrates enzymes was detected in larvae treated as $2^{\text {nd }}$ instars with $\mathrm{LC}_{50}$ of any of the three tested bioagents

On the other hand, treatment with the tested compounds caused disruption in the midgut tissue which therefore, must have caused disturbance of its digestive carbohydrase enzymes. These suggestion are supported by similar observations by Ishaaya et al., (1971) who mentioned that generally reduction in larval digestive enzymes could be an inhibitory effect of tested compounds as well as a result of its binding to inactive (zymogens) or active digestive enzymes.

The histological structure of the midgut in $S$. littoralis infected by the bioagents was affected. The mode of action of $B t$ is well documented, various proteins produced by the bacteria, known as $\square$ - endotoxin form crystals inside the bacteria. In midgut of susceptibly insects, this endotoxin become activated and is dissolved in the insect's midgut liberating the protoxins Gill et al., (1992). These protoxins bind to the midgut cells creating spores in the cell membrane and leading to equilibration of ions (Parenti et al., 1993). Furthermore, Van Rie et al., (1989) showed that the activated portions toxins disrupt the osmotic balance of these cells causing them to lyse. According to Sampson and Gooday, (1998), B.thuringiensis endogenous enzyme weakens the peritrophic membrane which allows more readily access of the bacterial toxins to the gut epithelia. Salama et al., (1993) showed that the initial destruction by Bt toxin facilitates the penetration and entry of virus. This observation might therefore explain the fact that the midgut epithelia were more impaired when Profect was used. 


\section{REFERENCES}

1. Abbott, W. S. 1925. A method for computing the effectiveness of an insecticide. J. Econ. Entoml., 18 : 265-267.

2. Chapman, R. F. 1988. The insects structure and function. $3^{\text {rd }}$ edition. English Language Book Society/ Edward Arnold. 50-52 pp.

3. Finney, D. J. 1971. Probit Analysis, A statistical treatment of the sigmoid response curve, $7^{\text {th }}$ Ed., Cambridge Univ. Press, Cambridge.

4. Gamil, W. E. 2004. Production of some bioformulations and study of their efficiency on some physiological traits in some insect species M. Sc. Thesis, Fac. Agric., Ain Shams Univ.

5. Gill, S. S., E. A. Colevles and P.V. Pietrantionia. 1992. The mode of action of Bacillus thuringiensis endotoxin. Annul. Rev. Entomol. 37: 615-636.

6. Hanafy, H.G.M., H.E.A. Sakrand W. El-Sayed. 2005. Toxicological and biochemical effects of bioagents products on the cotton leaf worm Spodoptera littoralis (Boisd.) (Lepidoptera: Noctuidea). Arab Univ. J. Agric. Sci.; Ain Shams Univ., Cairo, 13(3): 939-950.

7. Hegazy, E. and B.A. Antonious. 1987. Feeding deterrent efficacy of certain microbial insecticides against the cotton leaf worm, Spodoptera littoralis (Boisd.).Ann. Agric. Sci., Ain -Shams Univ., 32 (3): 1762 - 1772.

8. Ishaaya, I. and E. Swirski. 1970. Invertase and amylase activity in the armoured scales Chrysomphalus aonidium and Aonidella aurantii. J. Insect Physiol., 16: 1599-1606

9. Ishaaya, I., I.Moore and D. Joseph. 1971. Protease and amylase activity in larvae of the Egyptian cotton leaf worm, S. littoralis. J. Insect Physiol., 17: 945-953.

10. Lacey, L. A., R. Frutos., H. K Kaya. and P. Vails. 2001. Insect pathogens as biological control agents: Do they have a future?. Biological control, 21: 230248.

11. Mohamed, E.H. 2006. The use of three entomopathogens for controlling the cotton leaf worm Spodoptera littoralis (Boisd.) in the Egyptian clover fields as affective contribution to IPM programs. M. Sc. Thesis, Fac. Agric., Cairo Univ. 
442 THE EFFECT OF CERTAIN BIOCONTROL AGENT ON SOME BIOLOGICAL, BIOCHEMICAL AND HISTOLOGICAL ASPECTS OF THE COTTON LEAF WORM SPODOPTERA LITTORALIS (BOISD.)

(LEPIDOPTERA: NOCTUIDAE)

12. Mohamed, E.H., M. S. Abd El- Halim and M. M. El-Husseini. 2005. Efficacy and residual effect of Bacillus thuringiensis against larvae of cotton leaf worm Spodoptera littoralis (Boisd.) in the Egyptian clover fields. Egyptian J. Biol. Pest Control, 15 (2): 81-83.

13. Parenti, P., M.Villa, M. Taseca, P.Bbelgiojoso, G. M Manozet. and B. Giordana, (1993). A rapid and sensitive in vitro assay for the activity of Bacillus thuringinesis delta-endotoxin. Comp. Biochem. Physiol., 104 (2):375-390.

14. Salama, H. S., A.Sharaby, and M.M. El-Din. 1993. Mode of action of Bacillus thuringiensis and nuclear polyhedrosis virus in the larvae of Spodoptera littoralis (Bosid.).Insect Science applic. 14 (14):537-543.

15. Sampson, M. N. and G. W. Gooday. 1998. Involvement of chitinases of Bacillus thuringiensis during pathogenesis in insects. Microbiology, 144: 21892194.

16. Van Rie, J., S. Jansens, H. Hofte, D. Degheele and H. VanMellaart.1989. Specificity of Bacillus thuringiensis delta-endotoxin, Importance of specific receptors on the brush border membrane of the midgut of target insects. Europ. J. Biochem. 186: 239-247. 
تأثير بعض المركبات الحيوية على بعض النواحى البيولوجية والبيوكيميائية والهستوباثولوجية على دودة ورق القطن سبودبتر اليتور ايس

محمد سالم عبد الواحد ${ }^{2}$ فايزة مرعى أحمد1 ، عزيزة السبد عبد العال2 ، مروة محمد محمود2 1 - كلية الزراعة ، جامعة عبن شعس 2 - معرة بحوث وقابة النباتات ، مركز البحوث الزراعية ، الدقى كجيزة

وق استهدفت الاراسة الحالية ما يلى : 1 - تقييم فاعلية المركبات محل الدراسة ضد يرقات العمر الثانى لاودة ورق القطن : اختبرت فاعلية 3 مركبات حيوية وهى بروتكتو ، فيروست، وبروفكت و التىى أظهرت الآتى: كانت قيمة التركيز النصف مميت للمركبات بروتكتو ، فيروست ، وبروفكت المتحصل عليه عند PIB s/ml+IU/ml 2210X1.6 + معاملة يرقات العمر الثانى هى عند IU/ml 2²XX3.2 على التوالى. تم حساب الوقت اللازم لإماتة 50\% بالتركيز النصف مميت للبروتكتو ، فبروست ، وبروفكت هى 12.02 ، 12.47 ، 14.12 يوم على التو الى ـ كما تم حساب التركيزات الميتة اــ 90 \% من يرقات العمر الثانى لجميع المركبات محل الدراسة. 2 - تأثير المركبات المختبرة على بعض القياسات البيولوجية لاودة ورق القطن :

أظهرت النتائج عدم وجود فروق معنوية فى طول العمر اليرقى ليرقات العمر الثانى المعاملة بالبروتكتو ، فيروست وبروفكت ، حيث كان متوسط العمر اليرقى هو 14.5 ، 15 ، 15 يوم ، على التو الى ـ أدت المعاملة بالمركبات محل الدراسة إلى التأثير السلبى على نسبة التعذر فى اليرقات المعاملة فى العمر اليرقى الثانى حيث كانت نسبة التعذر 52.5 ، 50 ، 47.5\% ليرقات العمر الثانى المعاملة البروتكتو ، الفبروست و البروفكت على التو الى ـ تسببت المعاملة فى خفض فترة العمر العذرى بيوم واحد ليرقات العمر الثانى المعاملة البروفكت عن اليرقات غير المعاملة وسجلت متوسط 12.6 يوم • و عند معاملة برقات العمر الثانى بالبروتكتو والفيروست انخفضت فترة العمر العذرى بـ 2.3 يوم عن الكنترول بمتوسط 11.3 يوم لكلا المعاملتين. 
444 THE EFFECT OF CERTAIN BIOCONTROL AGENT ON SOME BIOLOGICAL, BIOCHEMICAL AND HISTOLOGICAL ASPECTS OF THE COTTON LEAF WORM SPODOPTERA LITTORALIS (BOISD.)

(LEPIDOPTERA: NOCTUIDAE)

\section{3 - التأثيرات الكيميائية الحيوية :}

تسببت المعاملة بالمركبات المختبرة عند تقدير نشاط إنزيمات الهضم المستخلصة من طحن برقات العمر السادس الناتجة من معاملة يرقات العمر الرابع بالمركبات محل الدراسة فى :

زيادة معنوية فى نشاط إنزيم الأميليز عند المعاملة بكل من البروتكتو والبروفكت ، بينما لم بسجل الفيروست فروق معنوية مقارنة باليرقات الغير معاملة ـ من جهة أخرى سجلت زيادة معنوية لنشاط إنزيم الإنفرتيز فى كل من البروتكتو و البروفكت و عدم وجود فروق معنوية للفيروست ـ وقد سجلت زيادة معنوية لنشاط إنزيم التزيهاليز لجميع المركبات محل الدراسة باستثناء البروتكتو حيث كانت التغير ات غير معنوية مقارنة باليرقات الغير معاملة. 4 - التأثير ات الهيستوباثولوجية المتأخرة: أوضحت هذه الدراسة التغيرات الهيستولوجية الناتجة من المعاملة فى طبقات المعى المتوسط ليرقات العمر السادس الناتجة من معاملة يرقات العمر الر ابع حديث الانسلاخ بالتركيز القاتل لـــ50\% من اليرقات المعاملة بالمركبات محل الدراسة ، وقد بينت هذه الدراسة تأثير جميع المركبات المستخدمة على طبقات المعى الأوسط مقارنة بمثيلتها فى اليرقات الغير معاملة ، وقد كان أكثر المركبات تأثنبر ا على المعى الأوسط هو مركب البروفكت يليه البروتكتو ثم الفيروست. 